\title{
Argentine Shortfin Squid (Illex argentinus) Stock Assessment in the Southwest Atlantic Using Geostatistical Techniques
}

\author{
Ke-Yang Chang ${ }^{1,2}$, Chih-Shin Chen ${ }^{3}$, Tsan-Yu Chiu ${ }^{4}$, Wen-Bin Huang ${ }^{5}$, and Tai-Sheng Chiu ${ }^{1, *}$ \\ ${ }^{1}$ Department of Life Science, National Taiwan University, Taipei, Taiwan, R.O.C. \\ ${ }^{2}$ Fisheries Research Institute, Council of Agriculture, Keelung, Taiwan, R.O.C. \\ ${ }^{3}$ Institute of Marine Affairs and Resource Management, National Taiwan Ocean University, Keelung, Taiwan, R.O.C. \\ ${ }^{4}$ Joint BioEnergy Institute and Physical Biosciences Division, Lawrence Berkeley National Laboratory, Berkeley, CA, U.S.A. \\ ${ }^{5}$ Department of Natural Resources and Environmental Studies, National Dong Hwa University, Hualien, Taiwan, R.O.C.
}

Received 13 January 2015, revised 13 November 2015, accepted 5 November 2015

\begin{abstract}
The spatial and temporal variation in Argentine shortfin squid Illex argentinus abundance distribution was examined over its fishing phase on the Patagonia Shelf and shelf break, Southwest Atlantic (SWA), using Taiwanese jigger's fishery data. Geostatistical techniques were applied to characterize the spatial and temporal variability in the squid abundance and its relation to seawater temperature. The experimental semivariograms indicated that the abundance of Argentine shortfin squid was spatially structured in the SWA, with various abundance levels. The spherical models for all years, except 2010, explained most spatial information from the annual squid abundance distribution patterns. The linear regression analysis confirmed a negative relationship between the annual squid abundance and seawater temperature in the studied years. High squid abundance was estimated using Kriging interpolations along the $200-\mathrm{m}$ isobath from $40^{\circ} \mathrm{S}$ to as far south as $50^{\circ} \mathrm{S}$. The elliptical isopleth lines extended a longer distance from the 200-m isobath to the shelf side in high abundance years, such as 1999 and 2007. Scattered patches of low values were observed in the very low-abundance year of 2004. The integrated total squid biomass using Kriging interpolation upheld a healthy stock status in the SWA fishing ground. Our research showed that the geostatistical procedure is effective in describing the annual spatial pattern, and the parameters resulting from stationary modeling are valuable and useful in estimating the annual total biomass in the realized fishing ground.
\end{abstract}

Key words: Illex argentines, Abundance, Geostatistics, Squid fishery

Citation: Chang, K. Y., C. S. Chen, T. Y. Chiu, W. B. Huang, and T. S. Chiu, 2016: Argentine shortfin squid (Illex argentinus) stock assessment in the Southwest Atlantic using geostatistical techniques. Terr. Atmos. Ocean. Sci., 27, 281-292, doi: 10.3319/TAO.2015.11.05.01(Oc)

\section{INTRODUCTION}

The Argentine shortfin squid Illex argentinus is commonly distributed in the Southwest Atlantic (SWA) from $22-54^{\circ} \mathrm{S}$, and is concentrated between 35 and $52^{\circ} \mathrm{S}$ along a 200-m isobath (Brunetti and Ivanovic 1992; Leta 1992; Jereb and Roper 2010). The precise Argentine shortfin squid identification from its sympatric congeners was improved using morphometric tools and beak characteristics (Martínez et al. 2002). The Argentine shortfin squid biology has been well-studied and a summary can be found in the reports published by Brunetti et al. (1998a) and Haimovici et al. (1998). The Argentine shortfin squid is a semelparous

\footnotetext{
* Corresponding author

E-mail:tschiu@ntu.edu.tw
}

organism with a short lifespan of about one year (Hatanaka 1986; Rodhouse and Hatfield 1990). Its development after the para-larval stage is continuous, with no sexual dimorphism and the growth rates are similar in immature males and females. The juveniles ( $<160 \mathrm{~mm}$ mantle length, ML) enter the neritic zone off Argentina and those larger than $180 \mathrm{~mm}$ recruit to the bottom. As a bottom dweller the squid exhibits diel vertical movement feeding on sub Antarctic macro zooplankton in the upper $25-40 \mathrm{~m}$ of the water column at night and returns to the bottom during the day (Jereb and Roper 2010). Spawning migration occurs when sub-adults (ML $>230 \mathrm{~mm}$ ) begin sexually maturing. Adults with an ML of $250-350 \mathrm{~mm}$ have been observed in oceanic waters (Parfenluk et al. 1992). Based on para-larvae occurrence and growth increment back-calculation in statoliths, the 
Argentine shortfin squid is suggested to spawn throughout the year (Rodhouse and Hatfield 1990; Rodhouse et al. 1995). Several stocks have been identified, including the one central Brazilian stock, and three Patagonian stocks that spawn in spring, summer and winter (Brunetti et al. 1998a, b; Haimovici et al. 1998; Perez et al. 2009). The winter spawners form the most prevalent group, of which two geographic stocks, i.e., the Bonaerensis-North Patagonia (BNPS) and the south Patagonia stocks (SPS), are recognized (Brunetti et al. 1998a; Haimovici et al. 1998).

Jigging fisheries targeting the Argentine shortfin squid have become a major industry contributing a substantial amount of world cephalopod production and created crucial economic value in the SWA (FAO 2012). Jiggers target the winter stocks in the Bonarensis-North Patagonian waters off southern Brazil (north of $44^{\circ} \mathrm{S}$ ) in January, and subsequently shift southward to the southern Patagonian area around the Falkland Islands (Malvinas) by May (Hatanaka 1986; Brunetti and Ivanovic 1992; Leta 1992; Rodhouse et al. 1995; Arkhipkin 2000). The major fishing season is from March to May, when the squids grow into the juvenile and sub-adult stages (approximately 230 - $300 \mathrm{~mm}$ ML). The production of the Argentine shortfin squid has increased dramatically since the 1980s when the jigger fleets from Asian countries paid their fishing efforts in the SWA. The global production of Illex argentinus was high in 1999 (approximately 1.1 million tons), and decreased sharply in 2004 (less than 0.13 million tons). The production recovered in 2007 (approximately 0.95 million tons), while a sharp decline again in 2010 (0.19 million tons, FAO 2012). The catch statistics reflected a substantial interannual fluctuation, up to a factor of 5 , which is characteristic for the squid fishery (Rodhouse 2001). Limitations on fishing efforts have been implemented by the Falkland Islands Fisheries Department to avoid high probabilities for low recruitment in the following year (Barton 2002). Although high fluctuation in the annual production has been observed in recent years, no regional fisheries management organization is in charge of the squid in this region.

Squids are species with a short life cycle and are characterized by having "fast lane" life-history traits, i.e., fast growth and early sexual maturity, with non-overlapping generations, which make their abundance vulnerable to sudden changes in environmental conditions (Anderson and Rodhouse 2001; Waluda et al. 2001a; Pierce et al. 2008). Assessment techniques for annual short-lived species are essential for feasible management, especially over the squid migratory ranges (Beddington et al. 1990; Pierce and Guerra 1994; Roa-Ureta and Arkhipkin 2007). Numerous traditional methods of abundance estimation, which are typically based on long-lived fin fish, are unsuitable for annual squid stocks (Pierce and Guerra 1994). Delury stock depletion methods have been suggested for some squid's stock assessments, e.g., Illex argentinus in the SWA (Bedding- ton et al. 1990; Rosenberg et al. 1990; Basson et al. 1996), and Ommastrephes bartramii in the North Pacific (Ichii et al. 2006; Chen et al. 2008) as well as in several regional loliginid species (Agnew et al. 1998; Young et al. 2004; Tian 2009). However, intensive data collection is required to achieve the proposed management target for sustainable fishery. Another approach for estimating squid abundance involves establishing empirical, heuristic models that relate squid abundance to environmental factors such as sea surface temperature (SST), sea bottom temperature, sea surface salinity, and atmospheric forcing (Pierce and Boyle 2003; Robinson et al. 2013; Chang et al. 2015). Oceanographic conditions have been reported to explain variability in squid abundance and distribution patterns (Waluda et al. 1999, 2001a, b, 2004; Agnew et al. 2002). Environmental factors may be critical in the squid recruitment process (Rodhouse 2001), however, these factors are difficult to predict. Thus, they are hardly applicable to fisheries management. Therefore, new methods must be developed to evaluate the squid stock status under high exploitation pressure.

The variability in Argentine shortfin squid abundance and distribution patterns could be explained by the local and regional environmental factors during their life cycles (Waluda et al. 1999, 2001a, b; Chen et al. 2007b). However, these empirical methods do not consider the spatial dynamics underlying the Argentine shortfin squid populations. Understanding the spatial and temporal dynamics and the spatial spread structure within fishing grounds is becoming increasingly crucial in managing straddling species such as the Argentine shortfin squid. The spatial dependence of a population is an innate quality and still difficult to describe in most ecological studies (Ciannelli et al. 2004). However, spatial information is critical for understanding the relationship between a population and its environment, especially for migratory squid, which can dynamically change their positions during their life cycles (Petitgas 1993, 2001; Agostini et al. 2008; Ciannelli et al. 2008). Geostatistical techniques consider population data with position information and differ from typical statistical estimations that include no spatial reference (Petitgas 1993). Because squid are short-lived species (approximately 1 year), their turnover systems may tend to be self-sustained and depart from the steady state in which case the spatial dependence of organisms becomes potential cues for deciphering their underlying population structures and annual abundance. Geostatistics is an effective technique used in quantifying spatial patterns and making estimations and predictions for population abundance (Isaaks and Srivastava 1989; Mello and Rose 2005; Faraj and Bez 2007). In this study we attempt to model the Argentine shortfin squid spatial structure in the SWA and estimate the annual total biomass in a realized fishing ground. This is the first study to apply geostatistical methods to the squid fishery. In addition, we discuss the implications of the proposed method for squid fisheries management. 


\section{MATERIALS AND METHODS}

\subsection{Study Area, Fishing Ground, and Dataset}

The study area is located in the SWA with a range of latitude and longitude $\left(36-54^{\circ} \mathrm{S}, 54-67^{\circ} \mathrm{W}\right)$ approximately similar to the distributional range of the Argentine shortfin squid (Fig. 1). The fishing ground range is defined by the summation of all grid-cells $(0.5 \times 0.5$ degree $)$ at least once occupied by the Taiwanese jigger fleet engaging in effective fishing during 1993 - 2012. This resulted in a realized fishing ground area of approximately 1.3 million $\mathrm{km}^{2}$, composed of 414 grid-cell units visited by individual vessels at various frequencies (Fig. 1). Three sub-areas (North, Middle, and South) were recognized reflecting fishing-site preference due to discontinuous density distribution along the Patagonia Shelf break. The delimit lines were latitudinal lines at 44 and $49^{\circ} \mathrm{S}$, respectively.

The Taiwanese jigging fleet is composed of approximately 100 vessels of similar lengths with gross tonnages of 720 - 950 tons and horsepower of 1600 - $2200 \mathrm{HP}$, equipped with approximately 50 - 60 jigging machines each. The Taiwanese jiggers harvest Argentine shortfin squid between January and June annually, with a peak in March through May. Daily operation records include size-categorized catch $(\mathrm{kg})$, geographic position, jigging depth, bottom depth, and in situ water temperature during fishing practice. Because all vessels have similar fishing equipment we use the number of jigging days (vessel-day, v-d) as a measurement for fishing effort. Moreover, using daily catch per unit effort (CPUE, $\mathrm{U}$ ) as an index of population abundance, the fishing efforts for each individual vessel were standardized using a method proposed by Chen and Chiu (2009). The method estimates the daily effort effectiveness based on a comparison of the nominal CPUE values from pairs of vessels that fished on the same day and at the same site $\left(0.5^{\circ} \times 0.5^{\circ}\right.$ grid-cell).

The squid abundance assessment was performed following a $0.5^{\circ} \times 0.5^{\circ}$ grid-cell pattern of CPUE. The annual CPUE remarkably fluctuated by more than 20 -fold (Fig. 2), with a mean of $10.99 \mathrm{t} \mathrm{v}^{-1} \mathrm{~d}^{-1}$ and standard deviation of $5.05 \mathrm{t} \mathrm{v}^{-1}$. Therefore 2 outlier years, 1999 and 2007, were selected to represent an extraordinary high abundance, and 1 outlier, 2004, was used to reflect an extraordinary low abundance. Another 3 years, 2010 - 2012, were chosen to analyze the recent stock status, among which 2010 was categorized moderate to low and 2011 and 2012 were considered ordinary years. Abundance index was nature logarithmic transformed $[\ln (\mathrm{U})]$ before subject to geostatistical procedure for mimicking a Gaussian distribution.

\subsection{Spatial Analysis}

The geostatistical method was applied to the yearly average abundance index of the Argentine shortfin squid in
$0.5 \times 0.5$ grid-cell. The method first quantifies the degree of autocorrelation between grid-cells and the obtained parameters were used for interpolations within the domain of the realized fishing ground. The experimental semivariograms $[\gamma(h)]$ comprised range-size categorized values from all possible paired comparisons to reflect variances that considered

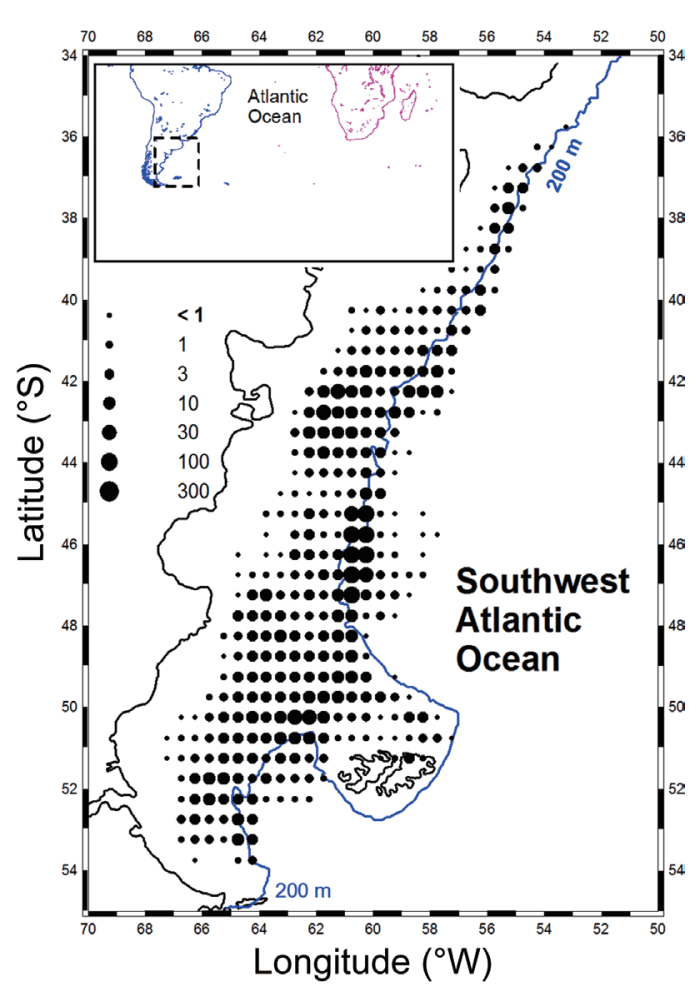

Fig. 1. Map showing Southwest Atlantic fishing ground for Argentine shortfin squid and spatial distribution of Taiwanese jigger fishing efforts (in vessel-day, v-d) over the past ten years (2003 - 2012). (Color online only)

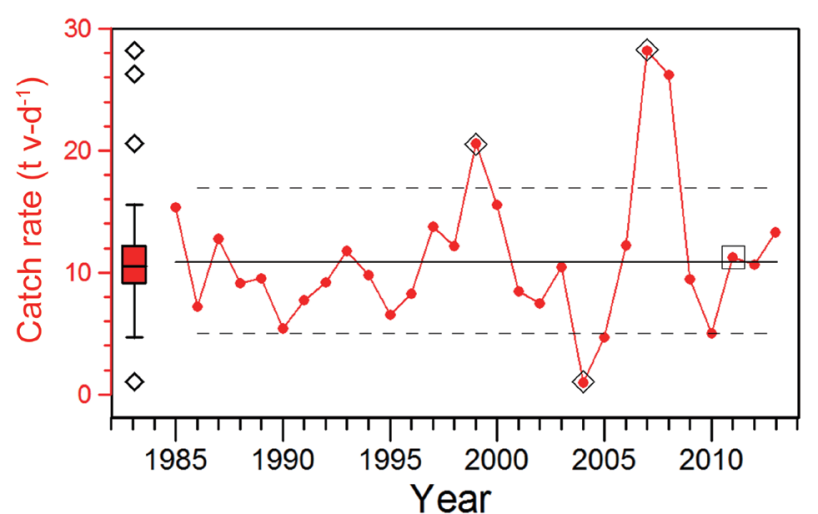

Fig. 2. Annual abundance index (in tons $\mathrm{v}-\mathrm{d}^{-1}$ ) from Taiwanese jiggers in the Southwest Atlantic waters. Box-and-whiskers plot summarized data across the whole range and dashed lines indicate $95 \%$ confident intervals. Four outliers are found with 1999, 2004, 2007, and 2008. Six years of 1999, 2004, 2007, 2010, 2011, and 2012 are selected to illustrate spatial patterns at abundance levels of high, ordinary and low. (Color online only) 
the spatial position of the grid-cell pairs. Matheron (1970) defined the semivariogram as follows:

$$
\begin{aligned}
& \gamma(h)=\left\{1 / 2 \mathrm{~N}(h) \times \operatorname{SUM}\left[\mathrm{Z}\left(\mathrm{v}_{\mathrm{i}}+h\right)-\mathrm{Z}\left(\mathrm{v}_{\mathrm{i}}\right)\right]^{2}\right\} \\
& \text { for } \mathrm{i}=1, \mathrm{~N}(h)
\end{aligned}
$$

where $\mathrm{Z}\left(\mathrm{v}_{\mathrm{i}}\right)$ denotes the abundance index, $\ln (\mathrm{U}+1)$ of $\mathrm{Ar}-$ gentine shortfin squid at grid-cell $\mathrm{v}_{\mathrm{i}}, \mathrm{Z}\left(\mathrm{v}_{\mathrm{i}}+h\right)$ is another abundance index value separated from the $\mathrm{v}_{\mathrm{i}}$ by a distance $h$. $\mathrm{N}(h)$ is the number of grid-cell pairs separated by $h$. The distance between locations 1 and 2 was calculated using their longitudinal ( $\mathrm{x}$ ) and latitudinal (y) values with square root of $\left(\mathrm{x}_{1}-\mathrm{x}_{2}\right)^{2}+\left(\mathrm{y}_{1}-\mathrm{y}_{2}\right)^{2}$, i.e., the unit measurement (1) equals $136.3 \mathrm{~km}$ centered at a latitudinal degree of $45^{\circ} \mathrm{S}$. The default lag distance was set to 0.5 (similar to the edge grid-cell) and ranged maximally by 10 lag numbers. The experimental variogram was modelled using the software Variowin ver. 2.2 (Pannatier 1996), and the criterion - indicative goodness of fit (IGF) was used to select the best model that explained the spatial structure of each year. Three parameters were obtained from the final model; the nugget effect $\left(\mathrm{C}_{\mathrm{o}}\right)$, which represents measurement error; the scale $(\mathrm{S})$, which is the maximum variability beyond which semivariance values become asymptotic; and the length (L), which denotes the distance within which the data remain auto-correlated.

\subsection{Kriging and Estimation of Total Biomass}

Semivariogram parameters from the selected model for each year were applied for the Kriging method in the software SURFER (SURFER for Windows ver. 6.0) to generate an interpolated abundance grid and a contour map for visual examination. All grid points were clipped using the realized fishing ground (Fig. 1), and the integrated volumes were used to estimate the annual total squid biomass. The exploitation rate $(\mathrm{E})$ is the percentage value estimated by the annual catch (C) to the annual total biomass (B); i.e., $\mathrm{E}=\mathrm{C} / \mathrm{B} \times 100 \%$. Because the main Argentine shortfin squid management target was set to maintain an escapement rate of higher than $40 \%$, the estimated exploitation rate can be a valuable reference in fishery regulation.

The percentage explanation of data variation (coefficient of determination, $\mathrm{R}^{2}$ ) was used in variographic analysis to indicate the goodness of fit of the model. The Kriging interpolations were evaluated using regression analysis, where a significantly positive correlation between the observed and estimated values is considered a valid estimation of the total biomass.

\subsection{Cross-Variography Between Abundance and Temperature}

Cross-variography is prepared to exhibit spatial correlation between the squid abundance index and water temperature. The cross-variogram was estimated using an approach similar to that used for the autovariogram of the squid abundance, and the formula is given as follows:

$$
\begin{array}{r}
\gamma(h)=\left\{1 / 2 \mathrm{~N}(h) \times \operatorname{SUM}\left[\mathrm{Z}\left(\mathrm{v}_{\mathrm{i}}+h\right)-\mathrm{Z}\left(\mathrm{v}_{\mathrm{i}}\right)\right] \times\right. \\
\left.\left[\mathrm{T}\left(\mathrm{v}_{\mathrm{i}}+h\right)-\mathrm{T}\left(\mathrm{v}_{\mathrm{i}}\right)\right]\right\} \quad \text { for } \mathrm{i}=1, \mathrm{~N}(h)
\end{array}
$$

where $\mathrm{Z}$ denotes the abundance index of the squid, and $\mathrm{T}$ denotes the water temperature, which was in situ temperature at about 5-m depth measured during fishing practice.

\section{RESULTS}

\subsection{Exploratory Statistical Analysis}

The annual squid abundance distribution patterns were categorized into 3 groups, namely high, ordinary, and low, according to the annual abundance index (Fig. 2). The geometric means for each year were $12.3 \pm 2.4,2.5 \pm 1.9$, $13.3 \pm 4.1,3.7 \pm 1.8,7.2 \pm 2.6$, and $8.8 \pm 1.8$, for 1999 , 2004, 2007, and $2010-2012$, respectively. The coefficient of variations ranged from 19.6\% (1999) to $77.3 \%$ (2004). Box-and-whisker plots revealed a few outliers within specific year, for instance lower ones in high abundance year 1999, and higher ones in low abundance year 2004. Some bi-directional outliers were observed in the ordinary 2012 , whereas no outliers were detected in 2007, 2010, and 2011. The original data were inspected for possible errors, while no errors were detected. Thus, all data were subjected to spatial pattern analyses.

\subsection{CPUE Semivariograms}

The experimental semivariograms indicated that annual Argentine shortfin squid abundance was spatially structured in the SWA, with various abundance levels (Fig. 3). Based on the IGF and coefficient of determination $\left(\mathrm{R}^{2}\right)$ criteria, we found that the spherical models for all years, except 2010, explained most spatial information for the annual squid abundance distribution patterns in the SWA (Table 1). Double functions were required for the year 1999; thus we employed a linear structure on the top of the spherical model. The combined model successfully reached the highest level of autocorrelation $\left(R^{2}=0.969\right)$. An exponential single model was preferred over a spherical one for explaining the spatial relationship in 2010 . The variogram models extracted less spatial information from the datasets of $2004(68.1 \%)$ and $2012(53.5 \%)$, which could also be confirmed by the coefficients of determination.

The percentage of nugget effect $\left(\mathrm{C}_{\mathrm{o}}\right)$ relative to the sill [Nugget + Scale $(\mathrm{S})$ ] ranged $7.4-41.2 \%$, indicating a suitable analytical resolution over the whole fishing ground in the year, in which semivariogram did not show any significant discontinuity in the origin due to analytical glitches. An 
exceptionally high percentage (41.2\%) was noted for 2012 , which was consistent with the exploratory statistical analysis phase, i.e., the most number of outliers was embedded in the 2012 dataset. By contrast, the spatial correlation component $(\mathrm{S})$ reflected a well-defined structure in all years.

Except for multi-structures in 1999, the length of spatial influence varied from 1.93 (2011) to 2.99 (2012), indicating a range-window of $25(5 \times 5)$ grid-cells (a compass of about 2.5 degrees) could be considered as the scope of spatial influence in the SWA fishing ground.

\subsection{Seawater Temperature and Cross-Correlation to Abundance}

The mean seawater temperatures in the fishing ground were $9.04 \pm 1.59,13.36 \pm 1.23,9.53 \pm 1.52,10.24 \pm 1.29$,
$11.31 \pm 1.57$, and $11.13 \pm 1.74\left({ }^{\circ} \mathrm{C}\right)$, in sequence of the studied years (Fig. 4). Almost constant within-year variations of $1.5^{\circ} \mathrm{C}$ were observed; however, significant different annual temperatures were evident. The annual average temperature patterns exhibited a suitable seawater temperature of $9-10^{\circ} \mathrm{C}$ in 1999 and 2007 , and a very high temperature of $13.36^{\circ} \mathrm{C}$ in 2004 . The linear regression analysis confirmed a negative relationship between the annual squid abundance and seawater temperature in the studied years.

The spatial correlation was demonstrated using crossvariography for the squid abundance index and seawater temperature (Fig. 5). The cross-variogram values $\gamma(h)$ illustrated an increasing trend in the abundance length in the high-abundance years, indicating the coupling of abundance and temperature in 1999 and 2007, and the ordinary year of 2012. However, a very short abundance length exhibited no
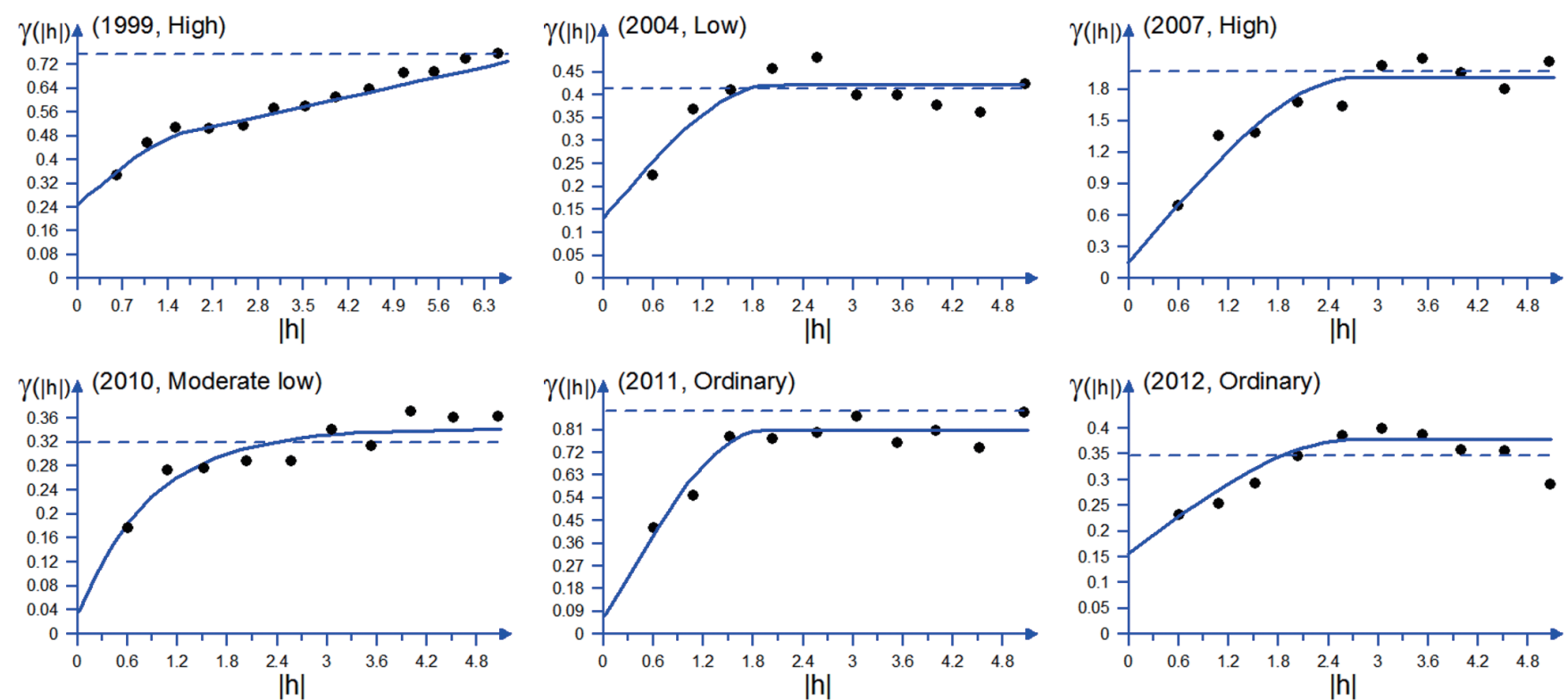

Fig. 3. Omnidirection semivariogram models for annual abundance index distributions with various abundance levels - 1999 (high), 2004 (low), 2007 (high), 2010 (moderate low), 2011 (ordinary), and 2012 (ordinary). Dashed line indicates the variance in annual abundance index. (Color online only)

Table 1. Parameters and goodness of fit for variogram model estimation for Illex argentinus in the Southwest Atlantic.

\begin{tabular}{|c|c|c|c|c|c|c|}
\hline \multirow{2}{*}{ Year } & \multirow{2}{*}{ Model } & \multicolumn{4}{|c|}{ Parameters } & \multirow{2}{*}{$\begin{array}{c}\text { Goodness of fit } \\
\mathbf{R}^{2} \\
\end{array}$} \\
\hline & & Nugget & Scale & Length & $\%$ & \\
\hline \multirow{2}{*}{1999} & \multirow{2}{*}{ Linear + Spherical } & 0.05 (Slope) & & & & \\
\hline & & 0.240 & 0.176 & 1.716 & 96.2 & 0.969 \\
\hline 2004 & Spherical & 0.130 & 0.297 & 2.075 & 68.1 & 0.690 \\
\hline 2007 & Spherical & 0.160 & 1.766 & 2.805 & 87.6 & 0.879 \\
\hline 2010 & Exponential & 0.036 & 0.304 & 2.703 & 84.3 & 0.844 \\
\hline 2011 & Spherical & 0.059 & 0.739 & 1.930 & 88.0 & 0.881 \\
\hline 2012 & Spherical & 0.154 & 0.220 & 2.993 & 53.5 & 0.707 \\
\hline
\end{tabular}




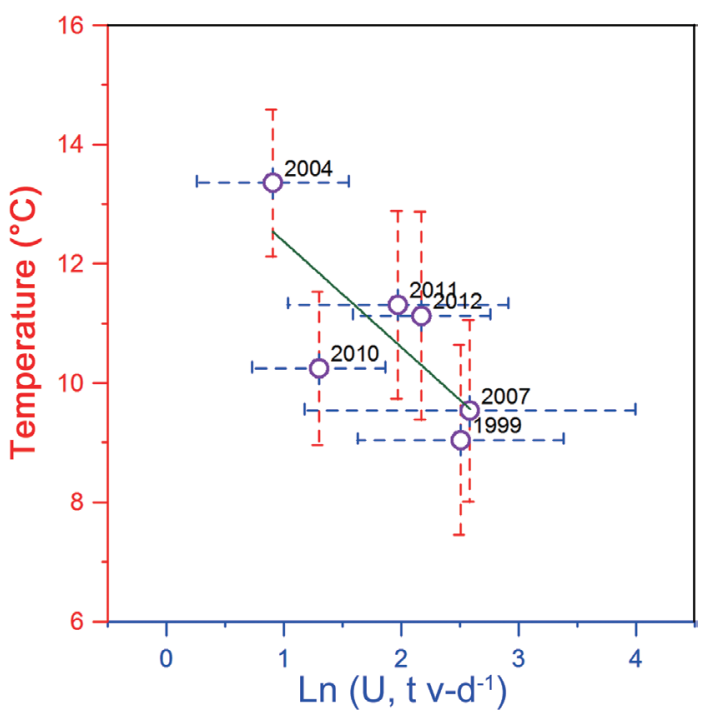

Fig. 4. Bivariate plot of abundance index [shown by $\ln (\mathrm{CPUE}+1)]$ and in situ seawater temperature. Negative correlation is evidenced by linear regression analysis, that shows a high temperature in 2004 corresponds to low abundance, and low temperatures in 1999 and 2007 follow high abundance. Dashed line indicates the standard deviation range. (Color online only)
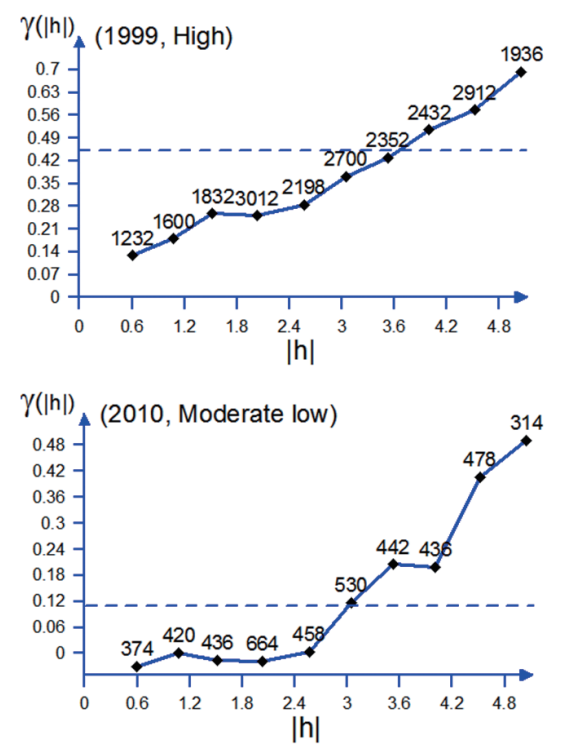
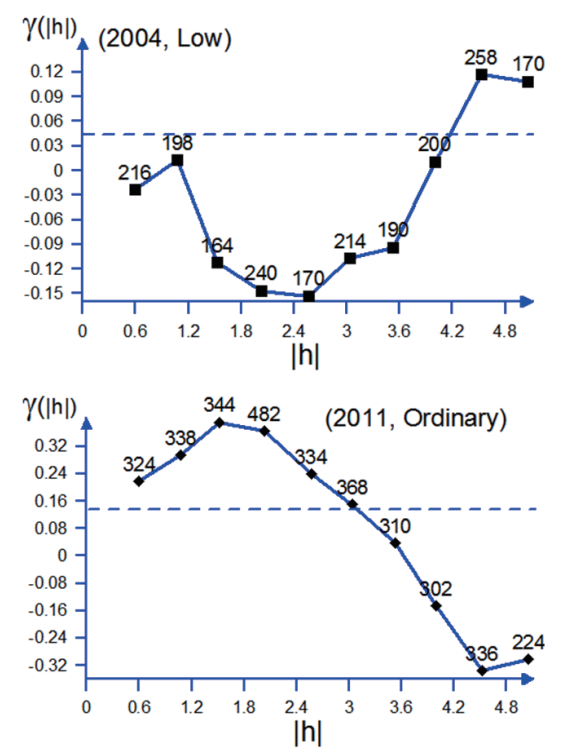
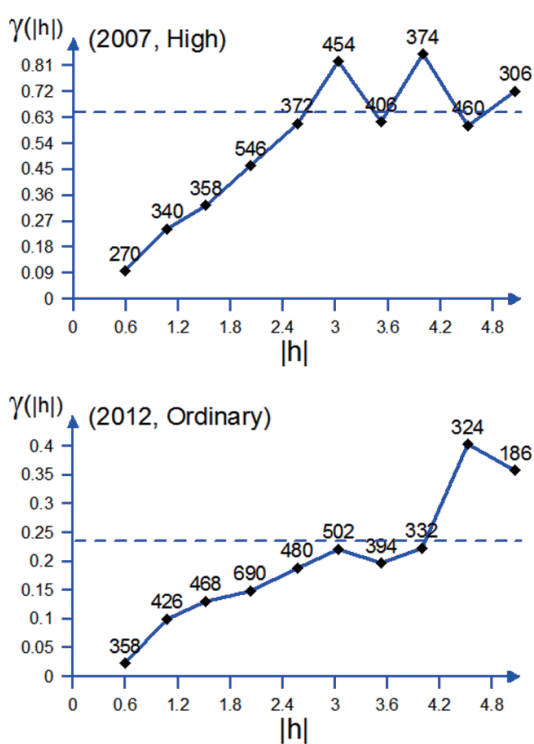

Fig. 5. Cross variography for variables for abundance and water temperature as shown by various abundance levels - 1999 (high), 2004 (low), 2007 (high), 2010 (moderate low), 2011 (ordinary), and 2012 (ordinary). Dashed line indicates covariance for abundance and temperature. (Color online only)

or a weak coupling in the low-abundance years (2004 and 2010) and the ordinary year of 2011.

\subsection{Total Biomas Kriging and Estimation}

The cross-validation analysis supported the validity of the spherical and exponential models, and these parameters are valuable for Kriging estimations (Fig. 6). All regressions between the observed and estimated values showed significant linear relationships with various slopes. The coefficient of determinations ranged from $0.811-0.981$, denoting that the Kriging estimations successfully interpreted the observations and an appealing smooth effect was also achieved (Fig. 7). In general, a high abundance was estimated along the $200-\mathrm{m}$ isobath from $40^{\circ} \mathrm{S}$ to as far south as $50^{\circ} \mathrm{S}$. The elliptic isopleth lines from the 200-m isobath to the shelf side extended farther in the high-abundance years such as 1999 and 2007. Scattered patches of low values were observed in the very low-abundance year 2004.

The relative annual total squid biomass was estimated 
(Table 2). Higher squid biomass was found in 2007 (1 093013 tons), followed by 1999 (780 474 tons). The squid biomass ranged from 225776 to 400679 tons for ordinary years and a very low biomass (109 815 tons) was estimated in 2004. All exploitation rates were lower than $60 \%$ and complied with a tentative goal for conservation of a $40 \%$ escapement rate.

\section{DISCUSSION}

The annual Argentine shortfin squid recruitment in the SWA varied drastically in the studied years (Fig. 2). Various finfish related methods have been proposed for assessing the squid stock in the Patagonia Shelf and vicinities of the Falkland Islands (Malvinas) (Basson et al. 1996; Waluda et al. 2008), to realize its population dynamics and accordingly suggest practical measures for fisheries management. However, the physiology and life history of squid differ from those of finfish, prompting fishery ecologists to propose additional stock assessment methods for squid (Pierce and Guerra 1994; Pierce and Boyle 2003). Squid populations have no multi-year class buffered age structure to reach a steady state in their annual recruitment because they are semelparous organisms with a short lifespan, usually one year. Analyzing the hidden characteristics of squid populations may facilitate solving conservation issues for commercially exploited squid stocks (Boyle and Rodhouse 2005).

The Argentine shortfin squid fishery is an example for the depletion method application and for providing management measures for the squid fishery (Pierce and Guerra 1994). Squid abundance shows substantial interannual fluctuation, which might be influenced by changes in environmental conditions, long-distance migrations and management measures designed for economic exclusive zones. In addition, because squid are a short lived species with highly labile life-history traits that respond rapidly to changes in environmental conditions, recent studies have focused on the relationships between squid abundance and environmental factors (Waluda et al. 1999, 2001a, 2004). Oceanographic factors, such as SST, productivity, current and mesoscale oceanographic processes are certain to be critical factors during the squid recruitment process (Waluda et al. 2004). These factors are reflected in spatial dynamics. In our models we included in situ seawater temperature (equivalence to the remote sensed SST) but also spatial information to evaluate the abundance variability of the Argentine shortfin squid.

A geostatistical approach was applied in this study to model the spatial structure of the Argentine shortfin squid in the SWA, particularly related to the jigger fishing grounds. This is the first attempt, to our knowledge, to apply a method for exploring the intrinsic population density distribution pattern characteristics as represented by the abundance index (Fig. 3; Table 1). This study pragmatically estimated the annual squid recruitment size based on its spatial distribution pattern. The geostatistical procedure is effective in
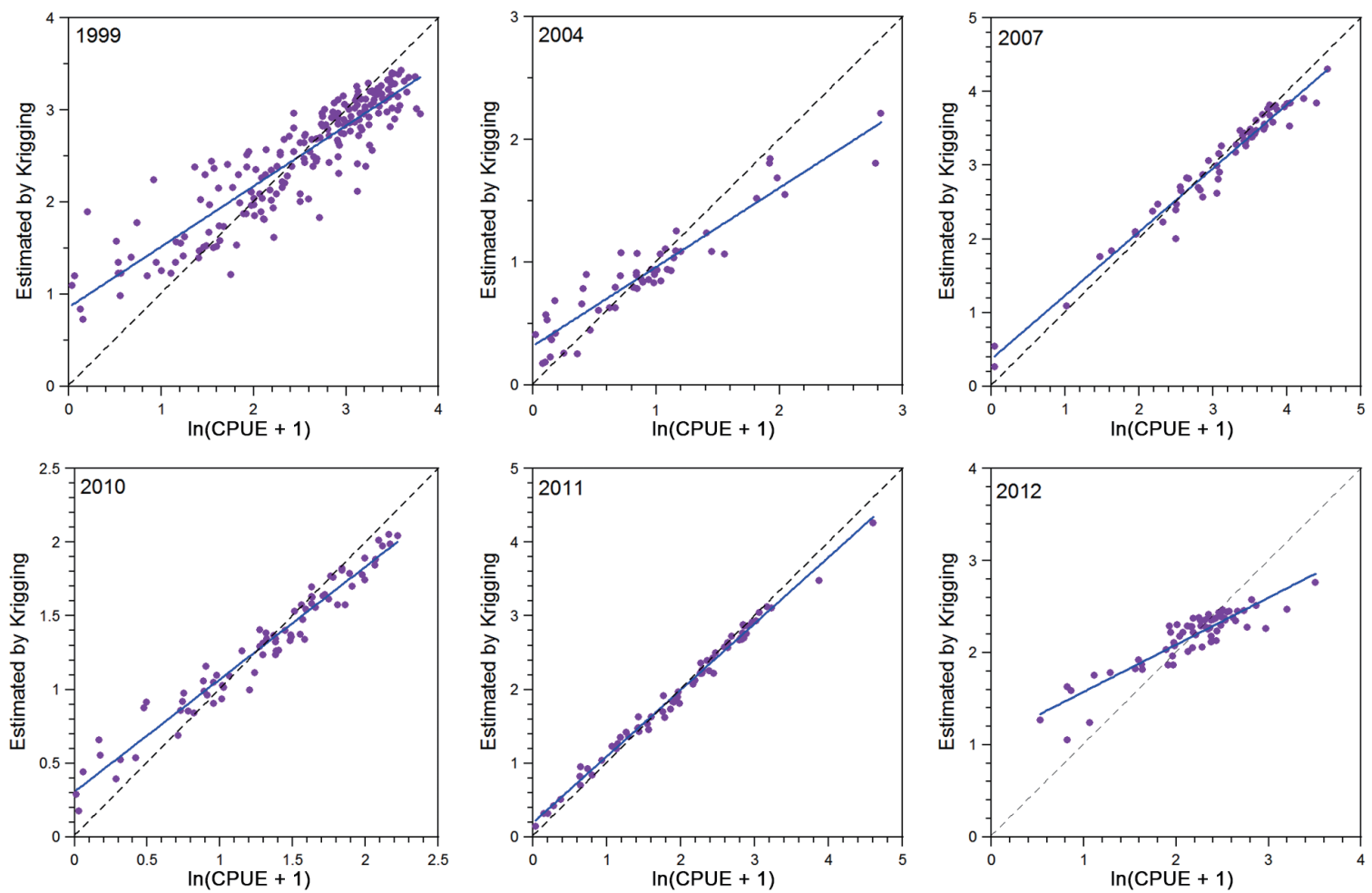

Fig. 6. Kriging results cross-validation as shown by linear correlations between the observation and estimation values. Dashed line indicates variance. (Color online only) 

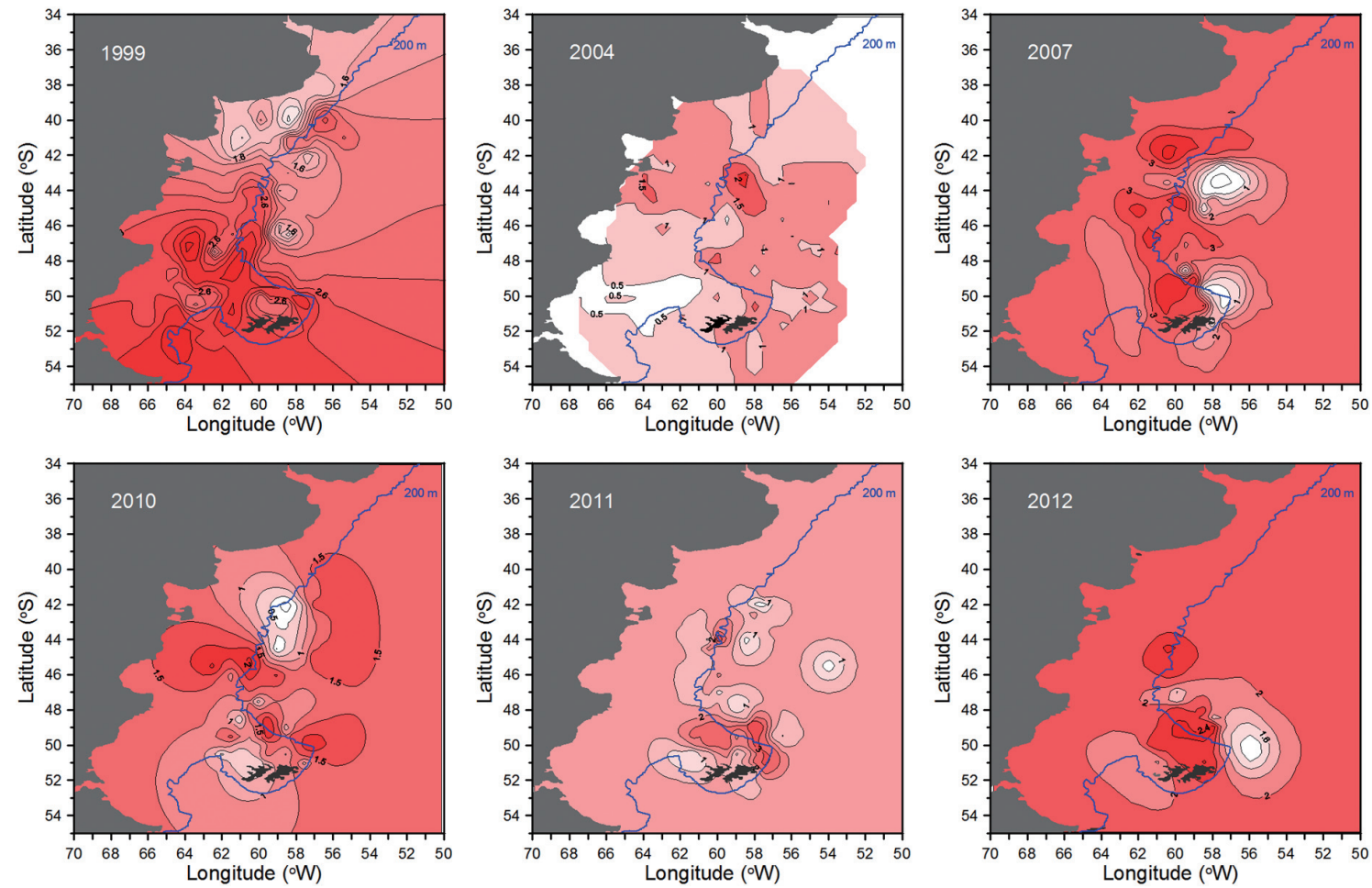

Fig. 7. Contour maps of the annual abundance index $[\ln (\mathrm{CPUE}+1)]$, intrapolations were made using the SURFER software Kriging gridding method incorporated with annual variogram model parameters (see Table 1). (Color online only)

Table 2. Cross-validation of Kriging estimate, average CPUE (U) and integrated annual biomass of Illex argentinus in the Southwest Atlantic squid jigging ground.

\begin{tabular}{lccccccccc}
\hline \multirow{2}{*}{ Year } & \multirow{2}{*}{ Model } & \multicolumn{3}{c}{ Cross-validation } & \multirow{2}{*}{ Avg. U } & Std & Biomass & Catch & Exp. rate \\
\cline { 3 - 5 } & & $\mathbf{a}$ & $\mathbf{b}$ & $\mathbf{r}^{2}$ & & & & \\
\hline 1999 & Linear + Spherical & 0.861 & 0.657 & 0.817 & 4.768 & 2.605 & 780474 & 263434 & $33.7 \%$ \\
2004 & Spherical & 0.319 & 0.664 & 0.885 & 0.928 & 0.399 & 109815 & 9767 & $8.9 \%$ \\
2007 & Spherical & 0.292 & 0.887 & 0.981 & 6.387 & 3.860 & 1093013 & 284562 & $26.0 \%$ \\
2010 & Exponential & 0.307 & 0.764 & 0.952 & 1.352 & 0.426 & 225776 & 30543 & $13.5 \%$ \\
2011 & Spherical & 0.195 & 0.901 & 0.990 & 2.040 & 1.248 & 258932 & 69577 & $26.9 \%$ \\
2012 & Spherical & 1.065 & 0.511 & 0.811 & 2.887 & 0.416 & 400697 & 83949 & $2.1 \%$ \\
\hline
\end{tabular}

delineating the annual spatial pattern and the parameters resulting from the stationary modeling are valuable and useful in estimating the annual total squid biomass in the realized fishing ground. The semivariogram modeling revealed that the spherical function for all years, except 2010, accurately described the squid abundance structures in the SWA fishing ground. In the high-abundance years 1999 and 2007 a common spatial structure pattern, which is expected to present similar parameters [nugget $\left(\mathrm{C}_{\mathrm{o}}\right)$, scale $(\mathrm{S})$ and length $(\mathrm{L})$ ] in the models, was not observed. However, the high annual production can account for the coherent spatial configurations. For instance, a linear model was first recognized in 1999 and extended to widespread fishing sites. Thus, a mod- erate to high squid concentration occurred extensively in the southern areas (Fig. 7), where area effect resulted in high annual production (Chen et al. 2007b). By contrast, the highest semivariance in 3 subareas were observed in 2007 (Table 2; Fig. 7), when the high-abundance effect resulted in the highest production ever. Conversely, as represented by the lowabundance year 2004, the spherical structure of the squid abundance was preserved under the condition of a relative low-value domain. Cooler subsurface seawater temperatures are crucial for the high Argentine shortfin squid abundance (Chang et al. 2015). The Argentine shortfin squid aggregates in the cold water area along the convergence of the Brazilian and Falkland currents (Chen et al. 2005) and forages in the 
Patagonia Shelf and around the Falkland Islands where cold waters along the confluence boundary of those currents might result in a region of high productivity (Chen et al. 2007a). In all cases, more than $50 \%$ of the scale was acquired from the abundance variance and an autocorrelation range stretching over approximately 2 geographic degrees implied the squid abundance spatial distribution in the SWA can be attributed to secondary-order stationary processes.

The grid values estimated using the parameterized Kriging technique indicated that these stationary processes were highly consistent with the observations (Fig. 6). The contour maps obtained from the Kriging revealed a reliable interpolation and demonstrated patchy arrangements with high-abundance cores and low-density holes, indicating non-uniform squid density distribution in the SWA (Fig. 7). The squid abundance means within each patch were spatially correlated depending on their separation distance rather than specific geographic positions. The Kriging technique results indicated that the annual squid biomass differed by 10 -fold between the highest- and lowest-production years (Table 2). For the Argentine shortfin squid fishery a management target of $40 \%$ proportional escapement has been suggested. A constant proportional escapement indicates a constant exploitation rate (Beddington et al. 1990). Considering the catch and estimated biomass, the exploitation rate for the Argentine shortfin squid in the SWA was $2.1-33.7 \%$, which indicates a healthy Argentine shortfin squid stock status.

The exploitation rate correlated with the biomass size and is also affected by environmental effects such as seawater temperature and fishing efforts. Many recent studies showed that the marine environmental factors play an important role in the spatial distribution of Argentine shortfin squid (Chen et al. 2007b; Piatkowski et al. 2001; Waluda et al. 2001a, b). The Argentine shortfin squid aggregates in the cold water area along the warm Brazilian and cold Falkland currents convergence (Chen et al. 2005). The unexpected high seawater temperature of $13.36^{\circ} \mathrm{C}$ in 2004 , compared to a suitable seawater temperature of $9-10^{\circ} \mathrm{C}$ in 1999 and 2007 , indicated an unfavorable environment for the squid that not only depressed the total biomass but also affected the aggregation pattern (Fig. 7). At low abundance level, as shown by low CPUE values in 2004 (Fig. 4), laying an adequate fishing effort at suitable fishing places could be a real challenge for skippers because the fleet did not manage to cut the annual total efforts short. Thus, the decoupling of squid schools and jigger lines reduced the fishing efficacy resulting in a low exploitation rate in 2004. Several signs accompanied the low exploitation rate in 2004 accordingly; (1) the coefficient of variation $(77.3 \%)$ of the catch rates among vessel was rather high, (2) variogram model extracted less spatial information from the logbook dataset (Fig. 3), and the lowest total biomass was estimated for the study period (Table 2).

Comparing our stock assessment results for the Ar- gentine shortfin squid with other studies is highly desirable, especially in light of regulations by escapement or exploitation rates. However, there is apparently no routine stock assessment in many targeted fisheries for squid (Rodhouse et al. 2014), except the neon shortfin squid in the northwest Pacific Ocean (Cao et al. 2015). Commercially exploited Argentine shortfin squid stocks are composed of fast growing short-life organisms, and DeLury depletion models were commonly suggested to match the fishing effort control measure in annual fishing practices (Beddington et al. 1990). For the part of stocks in the Falkland Islands Conservation Zone (FICZ), the species continue to be rich in the fishing ground based on annual licensing practice observations (Falkland Islands Government 2014). This study is the first attempt at using geographic annotated methods to facilitate stock assessment for the Argentine shortfin squid. Our estimations showed that all annual exploitation rates in the SWA fishing ground were less than $50 \%$, thus these findings could have lent valuable scientific support to certain extant management policies, at least in the FICZ (Table 2).

Remotely sensed SST are extensively used as a covariate to explain the variability in squid abundance (Agnew et al. 2000, 2002; Waluda et al. 2001b; Chen et al. 2007a, b). Seawater temperature as indicated by SST is an apparently environmental factor which influences the recruitment, abundance and distribution pattern of short-lived species, i.e., squid (Agnew et al. 2000). In the Argentine shortfin squid, Waluda et al. (1999, 2001a) showed that colder temperatures in the hatching area off the northern Patagonia Shelf indicated increased catch in the following fishing year and the favorable SST was in the range $16-18^{\circ} \mathrm{C}$. Wu et al. (2009) showed that the favorable SST for the Argentine shortfin squid in the fishing ground was $7-15^{\circ} \mathrm{C}$. Variable SST was selected in the optimal prediction model as generalized additive models (GAMs) were used to describe abundance variations in the Argentine shortfin squid (Sacau et al. 2005). These studies supported our result that the correlation between the Argentine shortfin squid abundance and in situ seawater temperature was significant (Figs. 4 and 5). Nevertheless, no studies have considered squid abundance and SST jointly with spatial references. In this study, the optimal in situ seawater temperature for high squid abundance was $9-10^{\circ} \mathrm{C}$, while higher temperatures reduced the squid abundance (Fig. 4). The cross-semivariogram elaborated this pattern, indicating the positive coupling of abundance and temperature at least within autovariogram ranges in high-abundance years (1999 and 2007; Fig. 5). However, abstruse or negative relationships were observed in ordinary and low-abundance years $(2004,2010$, and 2011). The cross-variogram revealed mixed patterns, suggesting that using SST or in situ water temperature as a proxy or an indicative variable for predicting the squid abundance may be conditional. For accurately understanding abundance fluctuations in the Argentine shortfin squid, using temperatures 
as predictor variables while ignoring the spatial factor may not be sufficient, especially in the high-abundance years.

\section{CONCLUSION}

We preliminarily adopted geostatistical techniques for stock assessment of the Argentine shortfin squid, whose life history traits differ from those of finfishes. The squid occurring in the SWA fishing ground departed from a uniform or random pattern, with various levels of auto-correlations. The Kriging results using obtained parameters for quantifying annual spatial structure are valuable because the interpolated values coincide highly with the observations from the fisheries. The total squid biomass for the studied years was estimated more than 2-fold higher than the annual catch, indicating that the Argentine shortfin squid remains in a healthy status under current fisheries exploitation.

Acknowledgements We thank the Overseas Fisheries Development Council of the Republic of China (Taiwan) for collecting fisheries logbooks, and the Fisheries Agency, Council of Agriculture for preparing the datasets. Financial support was funded in part by the Fisheries Agency, Council of Agriculture through grant No.: 102AS-11.1.1-FA-F5 (2), and the Ministry of Science and Technology through grant: No.: NSC 102-2313-B-002-022.

\section{REFERENCES}

Agnew, D. J., R. Baranowski, J. R. Beddington, S. des Clers, and C. P. Nolan, 1998: Approaches to assessing stocks of Loligo gahi around the Falkland Islands. Fish. Res., 35, 155-169, doi: 10.1016/S0165-7836(98)00083-6. [Link]

Agnew, D. J., S. Hill, and J. R. Beddington, 2000: Predicting the recruitment strength of an annual squid stock: Loligo gahi around the Falkland Islands. Can. J. Fish. Aquat. Sci., 57, 2479-2487, doi: 10.1139/f00-240. [Link]

Agnew, D. J., J. R. Beddington, and S. L. Hill, 2002: The potential use of environmental information to manage squid stocks. Can. J. Fish. Aquat. Sci., 59, 1851-1857, doi: 10.1139/f02-150. [Link]

Agostini, V. N., A. N. Hendrix, A. B. Hollowed, C. D. Wilson, S. D. Pierce, and R. C. Francis, 2008: Climateocean variability and Pacific hake: A geostatistical modeling approach. J. Mar. Syst., 71, 237-248, doi: 10.1016/j.jmarsys.2007.01.010. [Link]

Anderson, C. I. H. and P. G. Rodhouse, 2001: Life cycles, oceanography and variability: Ommastrephid squid in variable oceanographic environments. Fish. Res., 54, 133-143, doi: 10.1016/S0165-7836(01)00378-2. [Link]

Arkhipkin, A. I., 2000: Intrapopulation structure of winter- spawned Argentine shortfin squid, Illex argentinus (Cephalopoda, Ommastrephidae), during its feeding period over the Patagonian Shelf. Fish. Bull., 98, $1-13$.

Barton, J., 2002: Fisheries and fisheries management in Falkland Islands Conservation Zones. Aquat. Conservat. Mar. Freshwat. Ecosyst., 12, 127-135, doi: 10.1002/aqc.482. [Link]

Basson, M., J. R. Beddington, J. A. Crombie, S. J. Holden, L. V. Purchase, and G. A. Tingley, 1996: Assessment and management techniques for migratory annual squid stocks: The Illex argentinus fishery in the Southwest Atlantic as an example. Fish. Res., 28, 3-27, doi: 10.1016/0165-7836(96)00481-X. [Link]

Beddington, J. R., A. A. Rosenberg, J. A. Crombie, and G. P. Kirkwood, 1990: Stock assessment and the provision of management advice for the short fin squid fishery in Falkland Islands waters. Fish. Res., 8, 351-365, doi: 10.1016/0165-7836(90)90004-F. [Link]

Boyle, P. and P. Rodhouse, 2005: Cephalopods: Ecology and Fisheries, Blackwell Science Press, London, 452 pp, doi: 10.1002/9780470995310. [Link]

Brunetti, N. E. and M. L. Ivanovic, 1992: Distribution and abundance of early life stages of squid (Illex argentinus) in the south-west Atlantic. ICES J. Mar. Sci., 49, 175-183, doi: 10.1093/icesjms/49.2.175. [Link]

Brunetti, N. E., M. L Ivanovic, G. Rossi, B. Elena, and S. Pineda, 1998a: Fishery biology and life history of Illex argentinus. In: Okutani, T. (Ed.), Contributed Papers to International Symposium on Large Pelagic Squids, July $18-19$, 1996, for JAMARC's $25^{\text {th }}$ anniversary of its foundation, Japan Marine Fishery Resources Research Center (JAMARC), Tokyo, 217-231.

Brunetti, N. E., B. Elena, G. R. Rossi, M. L. Ivanovic, A. Aubone, R. Guerrero, H. Benavides, 1998b: Summer distribution, abundance and population structure of Illex argentinus on the Argentine shelf in relation to environmental features. S. Afr. J. Mar. Sci., 20, 175186, doi: 10.2989/025776198784126386. [Link]

Cao, J., X. Chen, and S. Tian, 2015: A Bayesian hierarchical DeLury model for stock assessment of the west winter-spring cohort of neon flying squid (Ommastrephes bartramii) in the northwest Pacific Ocean. Bull. Mar. Sci., 91, 1-13, doi: 10.5343/bms.2014.1020. [Link]

Chang, K. Y., C. S. Chen, H. Y. Wang, C. L. Kuo, and T. S. Chiu, 2015: The Antarctic Oscillation index as an environmental parameter for predicting catches of the Argentine shortfin squid (Illex argentinus) (Cephalopoda: Ommastrephidae), in southwest Atlantic waters. Fish. Bull., 113, 202-212, doi: 10.7755/FB.113.2.8. [Link]

Chen, C. S. and T. S. Chiu, 2009: Standardising the CPUE for the Illex argentinus fishery in the Southwest Atlantic. Fish. Sci., 75, 265-272, doi: 10.1007/s12562-0080037-1. [Link] 
Chen, C. S., T. S. Chiu, and W. B. Haung, 2007a: The spatial and temporal distribution patterns of the Argentine short-finned squid, Illex argentinus, abundances in the Southwest Atlantic and the effects of environmental Influences. Zool. Stud., 46, 111-122.

Chen, C. S., W. B. Haung, and T. S. Chiu, 2007b: Different spatiotemporal distribution of Argentine short-finned squid (Illex argentinus) in the Southwest Atlantic during high-abundance year and its relationship to sea water temperature changes. Zool. Stud., 46, 362-374.

Chen, X., B. Liu, and Y. Wang, 2005: Study on the distribution of production of Illex argentinus and its relationship with sea surface temperature in the southwest Atlantic Ocean in 2000. J. Zhanjiang Ocean Univ., 25, 29-34.

Chen, X., Y. Chen, S. Tian, B. Liu, and W. Qian, 2008: An assessment of the west winter-spring cohort of neon flying squid (Ommastrephes bartramii) in the Northwest Pacific Ocean. Fish. Res., 92, 221-230, doi: 10.1016/j.fishres.2008.01.011. [Link]

Ciannelli, L., K. S. Chan, K. M. Bailey, and N. C. Stenseth, 2004: Nonadditive effects of the environment on the survival of a large marine fish population. Ecology, 85, 3418-3427, doi: 10.1890/03-0755. [Link]

Ciannelli, L., P. Fauchald, K. S. Chan, V. N. Agostini, and G. E. Dingsør, 2008: Spatial fisheries ecology: Recent progress and future prospects. J. Mar. Syst., 71, 223236, doi: 10.1016/j.jmarsys.2007.02.031. [Link]

Falkland Islands Government, 2014: Fisheries Department Fisheries Statistics, Volume 18, 2013, FIG Fisheries Department, Stanley, Falklands Islands, 100 pp.

FAO, 2012: FAO Yearbook: Fishery and Aquaculture Statistics 2010, Food and Agriculture Organization of the United Nations, Rome, Italy.

Faraj, A. and N. Bez, 2007: Spatial considerations for the Dakhla stock of Octopus vulgaris: Indicators, patterns, and fisheries interactions. ICES J. Mar. Sci., 64, 18201828, doi: 10.1093/icesjms/fsm160. [Link]

Haimovici, M., N. E. Brunetti, P. G. Rodhouse, J. Csirke, and R. H. Leta, 1998: Illex argentinus. In: Rodhouse, P. G., E. G. Dawe, and R. K. O‘Dor (Eds.), Squid Recruitment Dynamics: The Genus Illex as a Model, the Commercial Illex Species, Influences on Variability, FAO Fisheries Technical Paper, No. 376, Food and Agriculture Organization, Rome, 27-58.

Hatanaka, H., 1986: Growth and life span of short-finned spuid Illex argentinus in the waters off Argentina. Nippon Suisan Gakk., 52, 11-17, doi: 10.2331/suisan.52.11. [Link]

Ichii, T., K. Mahapatra, H. Okamura, and Y. Okada, 2006: Stock assessment of the autumn cohort of neon flying squid (Ommastrephes bartramii) in the North Pacific based on past large-scale high seas driftnet fishery data. Fish. Res., 78, 286-297, doi: 10.1016/j. fishres.2006.01.003. [Link]

Isaaks, E. H. and R. M. Srivastava, 1989: Applied Geostatistics, Oxford University Press, New York, 561 pp.

Jereb, P. and C. F. E. Roper, 2010: Cephalopods of the World: An Annotated and Illustrated Catalogue of Cephalopod Species Known to Date, Vol. 2, Myopsid and Oegopsid Squids, FAO Species Catalogue for Fishery Purposes, FAO, Rome, 605 pp.

Leta,H.R., 1992: Abundance and distribution of rhynchoteuthion larvae of Illex argentlnus (Cephalopoda: Ommastrephidae) in the south-western Atlantic. S. Afr. J. Mar. Sci., 12, 927-941, doi: 10.2989/02577619209504753. [Link]

Martínez,P., A. Sanjuan, and A. Guerra, 2002: Identification of Illex coindetii, I. illecebrosus and I. argentinus (Cephalopoda: Ommastrephidae) throughout the Atlantic Ocean; by body and beak characters. Mar. Biol., 141, 131-143, doi: 10.1007/s00227-002-0796-7. [Link]

Matheron, G., 1970: La Théorie des Variables Régionalisées, et ses Applications, Ecole Nationale Supérieure des Mines de Paris, Paris, 212 pp.

Mello, L. G. S. and G. A. Rose, 2005: Using geostatistics to quantify seasonal distribution and aggregation patterns of fishes: An example of Atlantic cod (Gadus morhua). Can. J. Fish. Aquat. Sci., 62, 659-670, doi: 10.1139/ f04-227. [Link]

Pannatier, Y., 1996: VARIOWIN: Software for Spatial Data Analysis in 2D, Springer New York, 91 pp, doi: 10.1007/978-1-4612-2392-4. [Link]

Parfenluk, A. V., Y. M. Froerman, and A. N. Golub, 1992: Particularidades de la distribución de los juveniles del calamar (Illex argentinus) en el área de la depresión Argentina. Frente marítimo, 12, 105-111.

Perez, J. A. A., T. N. Silva, R. Schroeder, R. Schwarz, and R. S. Martins, 2009: Biological patterns of the Argentine shortfin squid Illex argentinus in the slope trawl fishery off Brazil. Lat. Am. J. Aquat. Res., 37, 1-19, doi: 10.3856/vol37-issue3-fülltext-1l. [Link]

Petitgas, P., 1993: Geostatistics for fish stock assessments: A review and an acoustic application. ICES J.Mar.Sci., 50, 285-298, doi: 10.1006/jmsc.1993.1031. [Link]

Petitgas, P., 2001: Geostatistics in fisheries survey design and stock assessment: Models, variances and applications. Fish Fish., 2, 231-249, doi: 10.1046/j.14672960.2001.00047.x. [Link]

Piatkowski, U., G. J. Pierce, and M. M. da Cunha, 2001: Impact of cephalopods in the food chain and their interaction with the environment and fisheries: An overview. Fish. Res., 52, 5-10, doi: 10.1016/S01657836(01)00226-0. [Link]

Pierce, G. J. and P. R. Boyle, 2003: Empirical modelling of interannual trends in abundance of squid (Loligo forbesi) in Scottish waters. Fish. Res., 59, 305-326, doi: 10.1016/S0165-7836(02)00028-0. [Link] 
Pierce, G. J. and A. Guerra, 1994: Stock assessment methods used for cephalopod fisheries. Fish. Res., 21, 255285, doi: 10.1016/0165-7836(94)90108-2. [Link]

Pierce, G. J., V. D. Valavanis, A. Guerra, P. Jereb, L. OrsiRelini, J. M. Bellido, I. Katara, U. Piatkowski, J. Pereira, E. Balguerias, I. Sobrino, E. Lefkaditou, J. Wang, M. Santurtun, P. R. Boyle, L. C. Hastie, C. D. MacLeod, J. M. Smith, M. Viana, A. F. González, and A. F. Zuur, 2008: A review of cephalopod-environment interactions in European Seas. Hydrobiologia, 612, 4970, doi: 10.1007/978-1-4020-9141-4_5. [Link]

Roa-Ureta, R. and A. I. Arkhipkin, 2007: Short-term stock assessment of Loligo gahi at the Falkland Islands: Sequential use of stochastic biomass projection and stock depletion models. ICES J. Mar. Sci., 64, 3-17, doi: 10.1093/icesjms/fs1017. [Link]

Robinson, C. J., J. Gómez-Gutiérrez, and D. A. S. de León, 2013: Jumbo squid (Dosidicus gigas) landings in the Gulf of California related to remotely sensed SST and concentrations of chlorophyll $a$ (1998-2012). Fish. Res., 137, 97-103, doi: 10.1016/j.fishres.2012.09.006. [Link]

Rodhouse, P. G., 2001: Managing and forecasting squid fisheries in variable environments. Fish. Res., 54, 3-8, doi: 10.1016/S0165-7836(01)00370-8. [Link]

Rodhouse, P. G. and E. M. C. Hatfield, 1990: Dynamics of growth and maturation in the cephalopod Illex argentinus de Castellanos, 1960 (Teuthoidea: Ommastrephidae). Phil. Trans. Biol. Sci., 329, 229-241, doi: 10.1098/rstb.1990.0167. [Link]

Rodhouse, P. G., J. Barton, E. M. C. Hatfield, and C. Symon, 1995: Illex argentinus: Life cycle, population structure, and fishery. ICES Mar. Sci. Symp., 199, 425-432.

Rodhouse, P. G. K., G. J. Pierce, O. C. Nichols, W. H. H. Sauer, A. I. Arkhipkin, V. V. Laptikhovsky, M. R. Lipiński, J. E. Ramos, M. Gras, H. Kidokoro, K. Sadayasu, J. Pereira, E. Lefkaditou, C. Pita, M. Gasalla, M. Haimovici, M. Sakai, and N. Downey, 2014: Environmental effects on cephalopod population dynamics: Implications for management of fisheries. Adv. Mar. Biol., 67, 99-233, doi: 10.1016/B978-0-12-8002872.00002-0. [Link]

Rosenberg, A. A., G. P. Kirkwood, J. A. Crombie, and J. R. Beddington, 1990: The assessment of stocks of annual squid species. Fish. Res., 8, 335-350, doi: 10.1016/0165-7836(90)90003-E. [Link]

Sacau, M., G. J. Pierce, J. Wang, A. I. Arkhipkin, J. Portela,
P. Brickle, M. B. Santos, A. F. Zuur, and X. Cardoso, 2005: The spatio-temporal pattern of Argentine shortfin squid Illex argentinus abundance in the southwest Atlantic. Aquat. Living Resour., 18, 361-372, doi: 10.1051/alr:2005039. [Link]

Tian, Y., 2009: Interannual-interdecadal variations of spear squid Loligo bleekeri abundance in the southwestern Japan Sea during 1975-2006: Impact of the trawl fishing and recommendations for management under the different climate regimes. Fish. Res., 100, 78-85, doi: 10.1016/j.fishres.2009.06.005. [Link]

Waluda, C. M., P. N. Trathan, and P. G. Rodhouse, 1999: Influence of oceanographic variability on recruitment in the Illex argentinus (Cephalopoda: Ommastrephidae) fishery in the South Atlantic. Mar. Ecol. Prog. Ser., 183, 159-167, doi: 10.3354/meps 183159. [Link]

Waluda, C. M., P. G. Rodhouse, G. P. Podestá, P. N. Trathan, and G. J. Pierce, 2001a: Surface oceanography of the inferred hatching grounds of Illex argentinus (Cephalopoda: Ommastrephidae) and influences on recruitment variability. Mar. Biol., 139, 671-679, doi: 10.1007/s002270100615. [Link]

Waluda, C. M., P. G. Rodhouse, P. N. Trathan, and G. J. Pierce, 2001b: Remotely sensed mesoscale oceanography and the distribution of Illex argentinus in the South Atlantic. Fish. Oceanogr., 10, 207-216, doi: 10.1046/j.1365-2419.2001.00165.x. [Link]

Waluda, C. M., P. N. Trathan, and P. G. Rodhouse, 2004: Synchronicity in southern hemisphere squid stocks and the influence of the Southern Oscillation and Trans Polar index. Fish. Oceanogr., 13, 255-266, doi: 10.1111/j.1365-2419.2004.00288.x. [Link]

Waluda, C. M., H. J. Griffiths, and P. G. Rodhouse, 2008: Remotely sensed spatial dynamics of the Illex argentinus fishery, Southwest Atlantic. Fish. Res., 91, 196202, doi: 10.1016/j.fishres.2007.11.027. [Link]

Wu, Y. M., S. L. Yang, J. H. Shen, W. F. Zhou, and J. Zhang, 2009: Fishing grounds characteristics of Illex argentinus in southwest Atlantic. Chin. J. Appl.Ecol., 20, 1445-1451.

Young, I. A. G., G. J. Pierce, H. I. Daly, M. B. Santos, L. N. Key, N. Bailey, J. P. Robin, A. J. Bishop, G. Stowasser, M. Nyegaard, S. K. Cho, M. Rasero, and J. M. F. Pereira, 2004: Application of depletion methods to estimate stock size in the squid Loligo forbesi in Scottish waters (UK). Fish. Res., 69, 211-227, doi: 10.1016/j. fishres.2004.04.013. [Link] 